\title{
Depreciation Choice and Future Operating Performance
}

\author{
Marcus L. Caylor \\ Associate Professor, Coles College of Business, Kennesaw State University \\ 560 Parliament Garden Way NW, Kennesaw, Georgia 30144, US
}

Scott Whisenant (Corresponding author)

Associate Professor, KU School of Business, The University of Kansas

Capitol Federal Hall, 1654 Naismith Dr., \#4173, Lawrence, Kansas 66045, US

Tel: 785-864-7577Ｅ-mail: scottwhisenant@ku.edu

Received: December 3, 2018 Accepted: January 14, 2019 Published: January 20, 2019

doi:10.5296/ijafr.v9i1.13997

URL: https://doi.org/10.5296/ijafr.v9i1.13997

\begin{abstract}
In this study we test the argument that information asymmetry and the problems of adverse selection provide incentives for managers to use accounting choices to signal relatively higher future prospects. Specifically, we contend that firms use accelerated depreciation to credibly signal higher future earnings and cash flows, consistent with signaling theory. Compared to straight-line depreciation, accelerated depreciation reduces earnings in the earlier years of asset lives and produces more variability in earnings. Despite these drawbacks, hundreds of firms voluntarily use accelerated depreciation for at least some of their depreciable assets. Our results indicate that the use of accelerated depreciation foreshadows higher future earnings and cash flows for horizons of one, two, and three years ahead.
\end{abstract}

Keywords: Financial reporting, Depreciation choice, Operating performance, Signaling

\section{Introduction}

Accounting earnings are ascribed special importance by analysts (Brown 2001; Brown and Caylor 2005), investors (Dechow 1994; Kasznik and McNichols 2002), managers (DeAngelo 1988; Bartov et al. 2002), contracting parties (Holthausen 1981; Leftwich 1981; Watts and Zimmerman 1986, 1990), regulatory authorities (Jones 1991; Cahan 1992; Key 1997), and courts (DeAngelo 1986, 1990). Evidence suggests that managers are attuned to the importance that various stakeholders ascribe to earnings (Graham et al. 2005). A growing 


\section{$\Lambda$ Macrothink}

International Journal of Accounting and Financial Reporting

ISSN 2162-3082

2019, Vol. 9, No. 1

body of evidence indicates that managers expend considerable time and effort managing both accruals (Healy and Wahlen 1999; Fields et al. 2001) and operating activities (Bartov 1993; Roychowdhury 2006; Xu et al. 2007; Cohen et al. 2008) to meet earnings thresholds. Evidence also suggests that managers oppose accounting standards that reduce earnings or increase earnings volatility and, in some cases, are willing to forego real economic value to improve near-term earnings (Mittelstaedt et al. 1995; Dechow et al. 1996; Bushee 1998; Espahbodi et al. 2002; Bhojraj and Libby 2005; Graham et al. 2005; Hodder et al. 2006; Jackson 2008) (Note 1).

Given the importance widely ascribed to earnings, the voluntarily use of accounting methods that both reduce near-term earnings and increase earnings volatility is puzzling. Nonetheless, evidence reveals that hundreds of firms use accelerated depreciation rather than straight-line depreciation. Bowen et al. (1995) find that approximately 30 percent of firms use accelerated depreciation for at least some of their depreciable assets. A natural question, given the earnings-related consequences of accelerated depreciation, is why managers make this choice (Note 2). In this study, we provide an explanation for why some firms rationally choose to use accelerated depreciation - managers provide private information through their choice of depreciation method that influences the beliefs of rational investors.

Using the intuition in Akerlof (1970), Ross (1977) illustrates that capital structure decisions may serve as credible signals about future firm performance. Leland and Pyle (1977) develop a model in which retained insider ownership signals firm quality in initial public offerings. The Leland and Pyle (1977) model suggests a positive relation between firm quality and leverage, much like Ross (1977). More recent studies find cash dividends, stock dividends, and stock splits can also serve as signals about higher future stock returns and better future operating performance (Healy and Palepu 1988; McNichols and Dravid 1990; Rankine and Stice 1997; Desai and Jain 1997).

Based on the signaling models in corporate finance and in the accounting literature (Bagnoli and Watts 2005), we empirically test whether an accounting choice (the use of accelerated depreciation) serves as a credible signal about future operating performance. For an accounting choice to be a reliable signal, the cost of the signal must be higher for low quality firms than for high quality firms. Therefore, we hypothesize that firms that use accelerated depreciation will report higher future earnings and cash flows than firms that use straight-line depreciation. Of course, signals have varying degrees of reliability. A signal is more reliable if it is increasingly costly (and prohibitively so) to mimic.

It is plausible that managers use a variety of signals in financial reporting disclosures, including a number of accounting choices. In our study, we focus on this specific accounting choice because the consequences of the choice are clear. Indeed, Ricks (1982, p. 71) indicates that "it might be reasonable to argue that depreciation is one accounting issue where the effects of different methods are obvious and well understood."

To test our hypotheses, we use the two stage Heckman procedure (Heckman 1979; Maddala 1983; Greene 2003) to control for endogeneity problems. In our primary tests, we estimate a first-stage probit model in which the depreciation choice is the dependent variable and 
economic determinants of that choice are the independent variables (Bowen et al. 1995). In the second stage model, the dependent variables are measures of future operating performance and the independent variables include (i) a dummy variable for whether the firm uses accelerated depreciation, (ii) economic determinants of future operating performance, and (iii) the inverse Mills ratio which controls for the potential selection bias of the depreciation choice.

In our models of future operating performance, we consistently find that the economic determinants of earnings and cash flows explain substantial fractions of the cross-sectional and temporal variation in these variables, consistent with prior research. In the presence of these economic determinants, we find that the use of accelerated depreciation is associated with higher levels of future earnings and cash flows (Note 3). This association is statistically significant at reliable levels for future earnings and cash flow (i.e., one, two, and three years ahead).

This study makes a contribution to the accounting literature. We provide initial evidence that depreciation choices can signal higher future prospects. This contribution to the accounting literature is distinct from the contributions of prior studies which have examined the market-related consequences (Archibald 1972; Kaplan and Roll 1972; Beaver and Dukes 1973), contracting consequences (Holthausen 1981; Leftwich 1981; Ricks 1982; Holthausen and Leftwich 1983; Watts and Zimmerman 1986; Fields et al. 2001), and capital investment consequences (Jackson 2008; Seybert 2010) of depreciation choice. Instead, we document that signaling theory appears (in part) to explain accounting choices made by managers.

The remainder of this study proceeds as follows. Section 2 develops the hypotheses that we empirically test. Section 3 describes the methodology and variable definitions. Section 4 provides the sample selection procedures and results. Section 5 provides further empirical evidence in supplemental analyses to enhance the reliability of our conclusions. The final section provides summary and concluding comments.

\section{Theory and Hypotheses}

\subsection{Background}

Corporate insiders have an informational advantage over diffuse external investors (Jensen and Meckling 1976; Leland and Pyle 1977; Copeland and Weston 1988; Eisenhardt 1989; Brennan 1990). In the presence of information asymmetry and the inability of market prices to fully reflect all information about firms' future prospects, firms are valued at average price (Riley 1979). That is, firms with more (less) favorable future prospects are undervalued (overvalued). In this setting, managers of firms that have favorable future prospects have incentives to find ways to credibly signal their private information to outside investors to avoid undervaluation (Akerlof 1970; Ross 1977; Leland and Pyle 1977; Riley 1979; Hirshleifer and Riley 1992; Milgrom and Roberts 1992).

Ross (1977) illustrates how financial policy decisions can serve as credible signals that help to resolve the information asymmetry problem that naturally arises when absentee owners delegate decision making authority to professional managers. For a financial policy signal to 
yield such a separating equilibrium, however, the cost of the signal must be decreasing in firm quality (Hirshleifer and Riley 1992; Copeland and Weston 1988; Milgrom and Roberts 1992; Spence 1973). That is, the cost of the signal must be higher for low quality firms than for high quality firms. The incentive-signaling paradigm has been posited as a way to understand a variety of financial policy and related decisions. For example, one stream of research contends that cash dividends, stock dividends, stock splits, and open market repurchases signal higher future stock returns and better operating performance (John and Williams 1985; Lakonishok and Lev 1987; Ofer and Siegel 1987; Barclay and Smith 1988; Brennan and Copeland 1988; Healy and Palepu 1988; McNichols and Dravid 1990; Ikenberry et al. 1996; Rankine and Stice 1997; Desai and Jain 1997).

A few examples of signaling theory are worthy of further exploration. Leland and Pyle (1977) analyze the role of signals within the process of initial public offerings (Note 4). They show that companies with good future prospects and higher possibilities of being successful (i.e., "good" companies) have incentives to signal to the market when going public (e.g., a significant percentage of the company will be retained by the owner). A reliable signal generally exists in the presence of information asymmetry and is viewed as too costly to be imitated by those companies with lower possibilities of success (i.e., "bad" companies). Leland and Pyle (1977) show that the costs (i.e., a relatively larger equity stake is more costly to a manager of a "bad" company) of imitating a signal are greater than the benefits. Similarly, Spence (1973) argues that a signal can be used to distinguish high and low productive workers. In his model, high productive workers can acquire education at a lower cost (e.g., less time, fewer direct costs, fewer other tradeoffs) than low productive workers. Spence illustrates how a signaling equilibrium exists in which high productive workers look for greater education in relation to low productive workers, and greater levels of education result in higher wages offered by employers. In his model, education serves as a reliable signal of potential productivity levels because the costs of mimicking are higher than the benefits (to low productive workers).

\subsection{Depreciation Choice and Future Operating Performance}

Although research suggests that managers use financial policy and related decisions to credibly signal higher future stock returns and operating performance, there is a limited amount of empirical evidence about the signaling role of accounting choices. With imperfect and incomplete markets, financial reporting disclosures can be efficient mechanisms to address market imperfections. Closely related to our motivation is empirical evidence that managers signal private information in accrual decisions. Subramanyam (1996) concludes that discretionary accruals are interpreted by investors as signals about the future financial prospects of firms. Louis and Robinson (2005) conclude that discretionary accruals recorded before stock-split announcements are interpreted by investors as signals of managerial optimism rather than managerial opportunism. However, research has yet to provide compelling evidence of whether accounting method choices are used by managers to credibly signal the favorable future prospects of firms. 


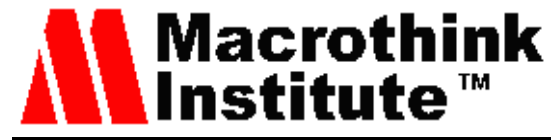

International Journal of Accounting and Financial Reporting

ISSN 2162-3082 2019, Vol. 9, No. 1

For an accounting choice to credibly signal higher future operating performance, the alternative accounting method must produce costs that are decreasing in firm quality, making the choice especially costly for firms with poor future prospects to imitate. Evidence suggests that firms' depreciation choice fits this requirement. Although the total amount of depreciation expense will be the same regardless of the choice of depreciation method (Note 5), the choice of accelerated depreciation produces less short-term earnings and more variability in earnings.

The culture in many organizations emphasizes the primacy of financial performance measures (Morgan 1997; Jensen 2001). Earnings are often viewed as the single most important financial performance metric (Dechow 1994; Graham et al. 2005). Accounting choices that reduce near-term earnings and produce more variability in earnings are likely to be costly because such choices potentially (i) risk meeting earnings thresholds (Brown and Caylor 2005), (ii) reduce managerial compensation (Gaver and Gaver 1998; Murphy 1999; Matsunaga and Park 2001), (iii) increase the likelihood of debt covenant violation (Watts and Zimmerman 1986, 1990; Sweeney 1994; DeFond and Jiambalvo 1994), (iv) reduce firms' ability to raise external capital (Graham and Harvey 2001), (v) increase managerial turnover (Farrell and Whidbee 2003; Engel et al. 2003), (vi) decrease earnings predictability (Dichev and Tang 2009), and (vii) increase the perceived riskiness of the firm (Graham et al. 2005).

Bagnoli and Watts (2005) offer a set of conditions that support a separating equilibrium for the signal in a depreciation choice. They show that investors can use the discretion in depreciation to infer private information about future prospects. As the costs of lower earnings and higher variability are expected to be relatively high for companies with poor future prospects, those managers will not mimic the depreciation reporting choice of managers who believe their firm's prospects are relatively strong. At a minimum, we can conclude that the cost of the accelerated depreciation choice signal is decreasing (increasing) for firms with higher (lower) future prospects. Our hypothesis, stated in alternative form, is as follows:

Hypothesis: Firms use the choice of accelerated depreciation as a positive signal to higher quality firms as evidenced by higher future prospects.

We operationalize this hypothesis by testing whether firms that choose accelerated depreciation have more favorable future operating performance (in future earnings and future cash flows). That is, we predict a positive correlation between firm quality and the choice of accelerated depreciation.

\section{Methodology and Variables Measurement}

\subsection{Overview}

Firms can choose between straight-line depreciation and accelerated depreciation under generally accepted accounting principles (GAAP) and evidence suggests that firms' choice between these methods is non-random (Christie and Zimmerman 1994; Bowen et al. 1995). Therefore, we use the two stage Heckman procedure to account for the endogenous nature of firms' depreciation choice (Heckman 1979). In the first stage, we use a probit model where 
we regress depreciation choice on expected economic determinants of the decision. The key output of this model is the inverse Mills ratio, which is used in second stage models to control for the endogenous nature of firms' depreciation choice. In the second stage models, we estimate two models to test whether depreciation choice is associated with higher future performance using future earnings and cash flows. The independent variables in the second stage models are (i) a dummy variable for firms' depreciation choice, (ii) economic determinants of the dependent variable drawn from prior research, and (iii) the inverse Mills ratio, which is obtained from the first step probit model. A number of accounting studies have previously used the two stage Heckman procedure (e.g., see Shehata 1991; Christian et al. 1994; Leuz and Verrecchia 2000; Barton 2001; Kim et al. 2003; and Tucker 2007).

\subsection{Depreciation Choice Model}

Bowen et al. (1995) document a number of economic determinants of firms' depreciation choice. Their model is specified as follows: (Note 6)

$$
\begin{aligned}
\text { CHOICE }_{\mathrm{it}} & =\lambda_{0}+\lambda_{1} \mathrm{DUR}_{\mathrm{it}}+\lambda_{2} \mathrm{RD}_{\mathrm{it}}+\lambda_{3} \mathrm{LABOR}_{\mathrm{it}}+\lambda_{4} \mathrm{DPEN}_{\mathrm{it}}+\lambda_{5}\left(\mathrm{MFG}_{\mathrm{it}}{ }^{*} \mathrm{COGS}_{\mathrm{it}}\right) \\
& +\lambda_{6}\left(\mathrm{NMFG}_{\mathrm{it}}{ }^{*} \mathrm{COGS}_{\mathrm{it}}\right)+\lambda_{7} \mathrm{NP}_{\mathrm{it}}+\lambda_{8} \mathrm{ADV}_{\mathrm{it}}+\lambda_{9} \mathrm{LEVMV}_{\mathrm{it}}+\lambda_{10} \mathrm{DROA}_{\mathrm{it}} \\
& +\lambda_{11} \mathrm{SALE}_{\mathrm{it}}+\lambda_{12}\left(\mathrm{OG}_{\mathrm{it}}{ }^{*} \mathrm{SALE}_{\mathrm{it}}\right)+\varepsilon_{\mathrm{it}}
\end{aligned}
$$

\begin{tabular}{|c|c|}
\hline & $\begin{array}{l}=\text { dummy variable equal to } 1 \text { for firms that use the accelerated } \\
\text { depreciation method for all or some of their assets, and } 0 \text { for firms that } \\
\text { use the straight-line depreciation method; }\end{array}$ \\
\hline $\mathrm{DUR}_{\mathrm{it}}$ & 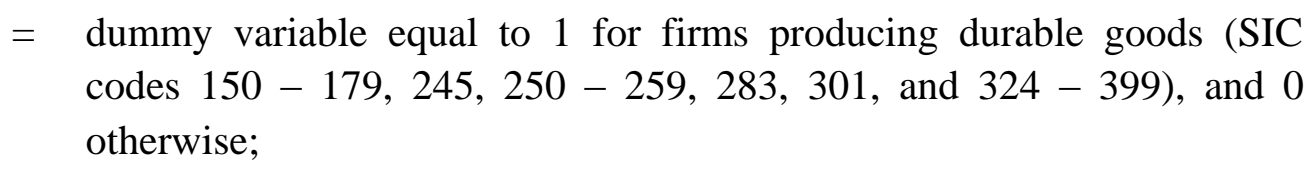 \\
\hline $\mathrm{RD}_{\mathrm{it}}$ & $\begin{array}{l}=\text { research and development expense scaled by } \mathrm{ADJ}_{-} \mathrm{TA}_{\mathrm{it}}(0 \text { if } \mathrm{RD} \\
\text { expense is missing); }\end{array}$ \\
\hline $\mathrm{LAB}$ & $\begin{array}{l}=\text { labor intensity measured as one minus the ratio of gross property, plant, } \\
\text { and equipment to ADJ_TA } \text { it }_{\text {, }}(0 \text { if gross property, plant, and equipment is } \\
\text { missing); }\end{array}$ \\
\hline DPEN $_{i t}$ & $\begin{array}{l}=\text { dummy variable equal to } 1 \text { for firms with defined benefit pension plans, } \\
\text { identified as those firms with a nonnegative value for projected pension } \\
\text { obligation or assumed rate of return for pension benefits, and } 0 \\
\text { otherwise; }\end{array}$ \\
\hline $\mathrm{MFG}_{\text {it }}$ & $\begin{array}{l}=\text { dummy variable equal to } 1 \text { for manufacturing firms (SIC codes } \\
\text { 200-399), and } 0 \text { otherwise; }\end{array}$ \\
\hline $\mathrm{NMFG}_{i t}$ & $\begin{array}{l}=\text { dummy variable equal to } 1 \text { for non-manufacturing firms (all SIC codes } \\
\text { except 200-399), and } 0 \text { otherwise; }\end{array}$ \\
\hline
\end{tabular}

where 


\begin{tabular}{|c|c|c|}
\hline $\mathrm{COGS}_{\mathrm{it}}$ & $=$ & cost of goods sold scaled by ADJ_TA \\
\hline $\mathrm{NP}_{\text {it }}$ & $=$ & notes payable scaled by ADJ_TA ${ }_{\text {it }}(0$ if notes payable is missing); \\
\hline $\mathrm{ADV}_{\text {it }}$ & $=$ & $\begin{array}{l}\text { advertising expense scaled by } \text { ADJ_TA }_{\text {it }}(0 \text { if advertising expense is } \\
\text { missing); }\end{array}$ \\
\hline $\mathrm{LEVMV}_{\text {it }}$ & $=$ & $\begin{array}{l}\text { ratio of long-term debt to market value of common stock ( } 0 \text { if long-term } \\
\text { debt is missing); }\end{array}$ \\
\hline DROA $_{\text {it }}$ & $=$ & $\begin{array}{l}\text { dummy variable equal to } 1 \text { for firms with return on assets (defined as } \\
\text { income before extraordinary items and discontinued operations scaled } \\
\text { by ADJ_TA } \mathrm{T}_{\text {it }} \text { ) in deciles } 2 \text { through } 9 \text {, where deciles are defined within } \\
\text { two-digit SIC codes, and } 0 \text { otherwise; }\end{array}$ \\
\hline SALE $_{\text {it }}$ & $=$ & natural logarithm of net sales in thousands; \\
\hline $\mathrm{OG}_{\mathrm{it}}$ & $=$ & $\begin{array}{l}\text { dummy variable equal to } 1 \text { for firms in the oil and gas industry (SIC } \\
\text { codes } 131 \text { and 291), and } 0 \text { otherwise; }\end{array}$ \\
\hline ADJ_TA $A_{i t}$ & $=$ & $\begin{array}{l}\text { average of beginning of year and end of year adjusted total assets, where } \\
\text { adjusted total assets are equal to total assets plus accumulated } \\
\text { depreciation; }\end{array}$ \\
\hline & & 1. \\
\hline
\end{tabular}

We scale variables by average adjusted total assets, similar to Bowen et al. (1995). This adjustment adds back accumulated depreciation so that we do not scale by a variable that is influenced by depreciation choice. We also combine firms that only use accelerated depreciation with those that use a mix of accelerated and straight-line depreciation in defining $\mathrm{CHOICE}_{\mathrm{it}}$. Our reason for doing this is because few firms use accelerated depreciation for all of their depreciable assets. In addition, our coding of $\mathrm{CHOICE}_{\mathrm{it}}$ is opposite by design of that in Bowen et al. (1995). Thus, the predicted signs of the coefficients are reversed. We make this coding change to help clarify the discussion of the results. Finally, because firms in our sample have repeated observations over time, we use clustered standard errors.

\subsection{Depreciation Choice and Future Operating Performance Model}

Prior theoretical and empirical research suggests a number of characteristics that are associated with future operating performance, and we draw on this literature. Our model expands the model in Barth et al. (2001) by adding (i) a dummy variable for firms' depreciation choice, (ii) additional economic determinants, and (iii) the inverse Mills ratio (discussed above). The model is specified as follows:

$$
\begin{aligned}
\mathrm{DV}_{-} 1_{\mathrm{it}+\mathrm{j}} & =\beta_{0}+\beta_{1} \mathrm{CHOICE}_{\mathrm{it}}+\beta_{2} \mathrm{CFO}_{\mathrm{it}}+\beta_{3} \Delta \mathrm{AR}_{\mathrm{it}}+\beta_{4} \Delta \mathrm{INV}_{\mathrm{it}}+\beta_{5} \Delta \mathrm{AP}_{\mathrm{it}} \\
& +\beta_{6} \mathrm{DEP}_{\mathrm{it}}+\beta_{7} \mathrm{AMORT}_{\mathrm{it}}+\beta_{8} \mathrm{OTHER}_{\mathrm{it}}+\beta_{9} \mathrm{CFO}_{\mathrm{it}-1}+\beta_{10} \mathrm{ACC}_{\mathrm{it}-1} \\
& +\beta_{11} \mathrm{RET}_{\mathrm{it}}+\beta_{12} \mathrm{EP}_{\mathrm{it}}+\beta_{13} \mathrm{CAP}_{\mathrm{it}}+\beta_{14} \mathrm{AGE}_{\mathrm{it}}+\beta_{15} \mathrm{ATO}_{\mathrm{it}} \\
& +\beta_{16} \mathrm{MILLS}_{\mathrm{it}}+\varepsilon_{\mathrm{it}}
\end{aligned}
$$


where

\begin{tabular}{|c|c|c|}
\hline DV_ $1_{i t+j}$ & $=$ & dependent variable, defined as either ADJ_INC $\mathrm{It}_{\mathrm{itj}}$ or $\mathrm{CFO}_{\mathrm{it}+\mathrm{j}}$; \\
\hline ADJ_INC ${ }_{i t+j}$ & $=$ & $\begin{array}{l}\text { income before extraordinary items and discontinued operations plus } \\
\text { depreciation expense scaled by ADJ_TA } A_{i t} \text {; }\end{array}$ \\
\hline $\mathrm{CFO}_{\mathrm{it+j}}$ & $=$ & $\begin{array}{l}\text { net cash flow from operating activities minus the accrual portion of } \\
\text { extraordinary items and discontinued operations reported on the } \\
\text { statement of cash flows scaled by ADJ_TA }\end{array}$ \\
\hline$\Delta \mathrm{AR}_{\mathrm{it}}$ & $=$ & $\begin{array}{l}\text { change in accounts receivable from the statement of cash flows scaled } \\
\text { by ADJ_TA } A_{\text {it }} \text { and multiplied by }-1 \text {; }\end{array}$ \\
\hline$\Delta \mathrm{INV}_{\text {it }}$ & $=$ & $\begin{array}{l}\text { change in inventory from the statement of cash flows scaled by } \\
\text { ADJ_TA } A_{\text {it }} \text { and multiplied by }-1 \text {; }\end{array}$ \\
\hline$\Delta \mathrm{AP}_{\mathrm{it}}$ & $=$ & $\begin{array}{l}\text { change in accounts payable and accrued liabilities from the statement } \\
\text { of cash flows scaled by ADJ_TA } A_{i t} \text {; }\end{array}$ \\
\hline $\mathrm{DEP}_{\mathrm{it}}$ & $=$ & $\begin{array}{l}\text { depreciation expense, computed as depreciation and amortization } \\
\text { expense minus amortization expense (coded as } 0 \text { if amortization } \\
\text { expense is missing) scaled by ADJ_TA } A_{i t} \text {; }\end{array}$ \\
\hline $\mathrm{AMORT}_{\text {it }}$ & $=$ & $\begin{array}{l}\text { amortization expense (coded as } 0 \text { if amortization expense is missing) } \\
\text { scaled by ADJ_TA } A_{i t} \text {; }\end{array}$ \\
\hline OTHER $_{\text {it }}$ & $=$ & $\begin{array}{l}\text { net of all other accruals, calculated as income before extraordinary } \\
\text { items and discontinued operations scaled by } \mathrm{ADJ}_{-} \mathrm{TA}_{\mathrm{it}}-\left(\mathrm{CFO}_{\mathrm{it}}+\right. \\
\left.\Delta \mathrm{AR}_{\mathrm{it}}+\Delta \mathrm{INV}_{\mathrm{it}}-\Delta \mathrm{AP}_{\mathrm{it}}-\mathrm{DEP}_{\mathrm{it}}-\mathrm{AMORT}_{\mathrm{it}}\right) \text {; }\end{array}$ \\
\hline $\mathrm{CFO}_{\text {it }-1}$ & $=$ & $\begin{array}{l}\text { net cash flow from operating activities minus the accrual portion of } \\
\text { extraordinary items and discontinued operations reported on the } \\
\text { statement of cash flows scaled by ADJ_TA }\end{array}$ \\
\hline $\mathrm{ACC}_{\mathrm{it}-1}$ & $=$ & total accruals scaled by ADJ_TA \\
\hline $\mathrm{RET}_{\text {it }}$ & $=$ & $\begin{array}{l}\text { stock return, computed as the year-to-year change in closing stock } \\
\text { price divided by the prior year closing stock price; }\end{array}$ \\
\hline $\mathrm{EP}_{\mathrm{it}}$ & $=$ & $\begin{array}{l}\text { earnings-to-price ratio if the ratio is nonnegative and } 0 \text { if the ratio is } \\
\text { negative, where the earnings-to-price ratio is defined as income before } \\
\text { extraordinary items and discontinued operations divided by the market } \\
\text { value of common equity; }\end{array}$ \\
\hline $\mathrm{CAP}_{\mathrm{it}}$ & $=$ & logarithm of the market value of common equity; \\
\hline $\mathrm{AGE}_{\mathrm{it}}$ & $=$ & logarithm of number of years firm has been listed on CRSP; \\
\hline $\mathrm{ATO}_{\mathrm{it}}$ & $=$ & asset turnover, defined as net sales divided by ADJ_TA ${ }_{i t}$; \\
\hline MILLS $_{\text {it }}$ & $=$ & inverse Mills ratio from estimation of Equation (1); \\
\hline $\mathrm{i}, \mathrm{t}$ & $=$ & firm and year subscripts, respectively; \\
\hline $\mathrm{j}$ & $=$ & 1,2 , and 3. \\
\hline
\end{tabular}




\section{Macrothink}

International Journal of Accounting and Financial Reporting

ISSN 2162-3082

The variable of interest in Equation (2) is $\mathrm{CHOICE}_{\mathrm{it}}$, and our theory predicts that its coefficient will be positive. Seven of the control variables in Equation (2) are drawn from Barth et al. (2001) $\left(\mathrm{CFO}_{\mathrm{it}}, \Delta \mathrm{AR}_{\mathrm{it}}, \Delta \mathrm{INV}_{\mathrm{it}}, \Delta \mathrm{AP}_{\mathrm{it}}, \mathrm{DEP}_{\mathrm{it}}, \mathrm{AMORT}_{\mathrm{it}}\right.$, and $\left.\mathrm{OTHER}_{\mathrm{it}}\right)$. The coefficients on these variables are predicted to be positive, except for the coefficient on $\triangle \mathrm{AP}_{\text {it }}$ which is predicted to be negative. Equation (2) also includes lags of disaggregated income $\left(\mathrm{CFO}_{\text {it-1 }}\right.$ and $\left.\mathrm{ACC}_{\text {it-1 }}\right)$ (Note 7). The coefficients on these variables are predicted to be positive. Finally, Equation (2) includes five economic determinants drawn from prior research $\left(\mathrm{RET}_{\mathrm{it}}, \mathrm{EP}_{\mathrm{it}}, \mathrm{CAP}_{\mathrm{it}}, \mathrm{AGE}_{\mathrm{it}}\right.$, and $\left.\mathrm{ATO}_{\mathrm{it}}\right)($ Note 8). We expect that the coefficient on $\mathrm{RET}_{\text {it }}$ to be positive because evidence shows that stock returns lead earnings (Beaver et al. 1980; Kothari and Sloan 1992). We expect the coefficient on $\mathrm{EP}_{\text {it }}$ to be negative because a smaller earnings-to-price ratio is an indicator of future growth in earnings (Penman 1996). We expect the coefficients on $\mathrm{CAP}_{i t}$ and $\mathrm{AGE}_{\text {it }}$ to be positive because larger and more mature firms are likely to have better future operating performance than smaller, less mature firms (Anthony and Ramesh 1992; Black 1998). Finally, we expect the coefficient on $\mathrm{ATO}_{\text {it }}$ to be positive because companies that more effectively utilize their assets are likely to have better future operating performance.

\section{Results}

\subsection{Sample Selection}

Our sample starts with 1988 and extends through 2005. We start with 1988 because this is the first year cash flows from operations are disclosed in the statement of cash flows. Following prior research, we exclude regulated industries (SIC codes between 4000-4999) and financial institutions (SIC codes between 6000-6999). We require that firms have the needed Compustat financial data to construct variables in Equations (1) and (2) and have positive sales and stockholders' equity (Note 9). After imposing these data restrictions, our sample for estimating Equations (1) and (2) consists of 56,303 firm years. To reduce the influence of outliers and extreme values on the results, we winsorize all variables (except for dummy variables and $\left.A G E_{i t}\right)$ at the $1^{\text {st }}$ and $99^{\text {th }}$ percentiles.

\subsection{Descriptive Statistics}

Table 1 provides the depreciation choice profile for our sample of 56,303 firm years by both year (Panel A) and industry (Panel B). Panel A shows that the popularity of straight-line depreciation choice has grown over our sample period. Panel B shows that our sample is a large cross-section of different industries. Our sample is comprised of 7,902 unique firms. The only industry that represents more than 10 percent of our sample firms is SIC two-digit classification 73. Also, the main depreciation choice in most industries is the straight-line method. 
Table 1. Depreciation choice and industry sample profile

Panel A. Depreciation choice profile by year

\begin{tabular}{llllllllll}
\hline & \multicolumn{2}{l}{ Straight-line } & \multicolumn{2}{l}{ Accelerated } & & \multicolumn{2}{l}{ Straight-line } & \multicolumn{2}{l}{ Accelerated } \\
\hline & \multicolumn{2}{l}{ depreciation } & \multicolumn{2}{l}{ Depreciation } & & depreciation & \multicolumn{2}{c}{ Depreciation } \\
\hline Year & $\#$ & $\%$ & $\#$ & $\%$ & Year & $\#$ & $\%$ & $\#$ & $\%$ \\
\hline 1988 & 352 & 70.68 & 146 & 29.32 & 1998 & 3,094 & 81.25 & 714 & 18.75 \\
\hline 1989 & 1,877 & 72.53 & 711 & 27.47 & 1999 & 2,973 & 82.38 & 636 & 17.62 \\
\hline 1990 & 2,023 & 73.01 & 748 & 26.99 & 2000 & 2,979 & 83.17 & 603 & 16.83 \\
\hline 1991 & 2,075 & 73.87 & 734 & 26.13 & 2001 & 3,036 & 84.38 & 562 & 15.62 \\
\hline 1992 & 2,242 & 75.46 & 729 & 24.54 & 2002 & 2,872 & 84.52 & 526 & 15.48 \\
\hline 1993 & 2,443 & 77.48 & 710 & 22.52 & 2003 & 2,785 & 84.55 & 509 & 15.45 \\
\hline 1994 & 2,686 & 78.81 & 722 & 21.19 & 2004 & 2,662 & 85.21 & 462 & 14.79 \\
\hline 1995 & 2,804 & 79.23 & 735 & 20.77 & 2005 & 2,174 & 85.42 & 371 & 14.58 \\
\hline 1996 & 2,980 & 80.13 & 739 & 19.87 & All years & 45,193 & 80.27 & 11,110 & 19.73 \\
\hline 1997 & 3,136 & 80.64 & 753 & 19.36 & & & & & \\
\hline
\end{tabular}

Panel B. Depreciation choice profile by industry

\begin{tabular}{llllll}
\hline SIC & & & $\%$ of & $\%$ & $\%$ \\
\hline code & SIC code description & $\#$ & total & SL & ACC \\
\hline 10 & Metal mining & 93 & 1.18 & 10.75 & 89.25 \\
\hline 13 & Oil and gas extraction & 349 & 4.42 & 15.47 & 84.53 \\
\hline 15 & Building construction general contractors & 55 & 0.70 & 74.55 & 25.45 \\
\hline 20 & Food and kindred products & 196 & 2.48 & 87.76 & 12.24 \\
\hline 22 & Textile mill products & 55 & 0.70 & 87.27 & 12.73 \\
\hline 23 & $\begin{array}{l}\text { Apparel and other finished products made from } \\
\text { fabrics }\end{array}$ & 91 & 1.15 & 75.82 & 24.18 \\
\hline 25 & Furniture and fixtures & 55 & 0.70 & 76.36 & 23.64 \\
\hline 26 & Paper and allied products & 91 & 1.15 & 59.34 & 40.66 \\
\hline 27 & Printing, publishing, and allied industries & 109 & 1.38 & 80.73 & 19.27 \\
\hline 28 & Chemicals and allied products & 711 & 9.00 & 86.50 & 13.50 \\
\hline
\end{tabular}




\begin{tabular}{|c|c|c|c|c|c|}
\hline 29 & Petroleum refining and related industries & 54 & 0.68 & 31.48 & 68.52 \\
\hline 30 & Rubber and miscellaneous plastics products & 108 & 1.37 & 79.63 & 20.37 \\
\hline 32 & Stone, clay, glass, and concrete products & 56 & 0.71 & 62.50 & 37.50 \\
\hline 33 & Primary metal industries & 131 & 1.66 & 80.15 & 19.85 \\
\hline 34 & Fabricated metal products & 121 & 1.53 & 83.47 & 16.53 \\
\hline 35 & $\begin{array}{l}\text { Industrial and commercial machinery and } \\
\text { equipment }\end{array}$ & 617 & 7.81 & 83.14 & 16.86 \\
\hline 36 & $\begin{array}{l}\text { Electronic and other electrical equipment and } \\
\text { components }\end{array}$ & 721 & 9.12 & 83.50 & 16.50 \\
\hline 37 & Transportation equipment & 182 & 2.30 & 76.37 & 23.63 \\
\hline 38 & $\begin{array}{l}\text { Measuring, analyzing, and controlling } \\
\text { instruments }\end{array}$ & 626 & 7.92 & 84.19 & 15.81 \\
\hline 39 & Miscellaneous manufacturing industries & 104 & 1.32 & 75.00 & 25.00 \\
\hline 50 & Wholesale trade durable goods & 259 & 3.28 & 77.61 & 22.39 \\
\hline 51 & Wholesale trade non-durable goods & 134 & 1.70 & 78.36 & 21.64 \\
\hline 53 & General merchandise stores & 58 & 0.73 & 94.83 & 5.17 \\
\hline 54 & Food stores & 52 & 0.66 & 92.31 & 7.69 \\
\hline 56 & Apparel and accessory stores & 68 & 0.86 & 92.65 & 7.35 \\
\hline 57 & $\begin{array}{l}\text { Home furniture, furnishings, and equipment } \\
\text { stores }\end{array}$ & 53 & 0.67 & 92.45 & 7.55 \\
\hline 58 & Eating and drinking places & 152 & 1.92 & 94.74 & 5.26 \\
\hline 59 & Miscellaneous retail & 200 & 2.53 & 89.00 & 11.00 \\
\hline 73 & Business services & 1,269 & 16.06 & 88.49 & 11.51 \\
\hline 78 & Motion pictures & 79 & 1.00 & 48.10 & 51.90 \\
\hline 79 & Amusement and recreation services & 102 & 1.29 & 85.29 & 14.71 \\
\hline 80 & Health services & 223 & 2.82 & 91.48 & 8.52 \\
\hline 87 & $\begin{array}{l}\text { Engineering, accounting, management, and } \\
\text { related services }\end{array}$ & 207 & 2.62 & 84.06 & 15.94 \\
\hline & Other SIC codes & 521 & 6.59 & 77.54 & 22.46 \\
\hline & Total & 7,902 & 100.0 & & \\
\hline
\end{tabular}


In both panels, "accelerated depreciation" captures firms that use accelerated depreciation for all or some of their assets. In Panel B, "Other SIC codes" captures 21 two-digit SIC codes containing fewer than 50 firms each.

Table 2 provides descriptive statistics for the variables used in Equations (1) and (2). Table 2 shows that the sample used to estimate Equations (1) and (2) includes 56,303 firm year observations. The sample is comprised of 45,193 firm years ( 80.27 percent of the sample) using straight-line depreciation and 11,110 firm years (19.73 percent of the sample) using accelerated depreciation.

Table 2. Descriptive statistics

\begin{tabular}{|c|c|c|c|c|c|c|}
\hline \multirow[b]{2}{*}{ Variables } & \multicolumn{2}{|c|}{$\begin{array}{l}\text { All firms } \\
(\mathrm{n}=56,303)\end{array}$} & \multicolumn{2}{|c|}{$\begin{array}{l}\text { Straight-line firms } \\
(\mathrm{n}=45,193)\end{array}$} & \multicolumn{2}{|c|}{$\begin{array}{l}\text { Accelerated firms } \\
(\mathrm{n}=11,110)\end{array}$} \\
\hline & Mean & Median & Mean & Median & Mean & Median \\
\hline $\mathrm{CHOICE}_{\mathrm{it}}$ & 0.1973 & 0.0000 & 0.0000 & 0.0000 & 1.0000 & 1.0000 \\
\hline DUR $_{\text {it }}$ & 0.4437 & 0.0000 & 0.4622 & 0.0000 & 0.3682 & 0.0000 \\
\hline $\mathrm{RD}_{\mathrm{it}}$ & 0.0444 & 0.0038 & 0.0497 & 0.0071 & 0.0225 & 0.0000 \\
\hline $\mathrm{LABOR}_{\text {it }}$ & 0.5929 & 0.6308 & 0.6241 & 0.6559 & 0.4659 & 0.4950 \\
\hline $\mathrm{DPEN}_{\mathrm{it}}$ & 0.2916 & 0.0000 & 0.2707 & 0.0000 & 0.3765 & 0.0000 \\
\hline $\mathrm{MFG}_{\mathrm{it}} * \mathrm{COGS}_{\mathrm{it}}$ & 0.3604 & 0.2483 & 0.3663 & 0.2571 & 0.3365 & 0.1896 \\
\hline $\mathrm{NMFG}_{\mathrm{it}} * \mathrm{COGS}_{\mathrm{it}}$ & 0.3424 & 0.0000 & 0.3639 & 0.0000 & 0.2548 & 0.0000 \\
\hline $\mathrm{NP}_{\text {it }}$ & 0.0241 & 0.0000 & 0.0236 & 0.0000 & 0.0259 & 0.0000 \\
\hline $\mathrm{ADV}_{\text {it }}$ & 0.0110 & 0.0000 & 0.0120 & 0.0000 & 0.0073 & 0.0000 \\
\hline $\mathrm{LEVMV}_{\text {it }}$ & 0.3492 & 0.0883 & 0.3438 & 0.0768 & 0.3711 & 0.1337 \\
\hline $\mathrm{DROA}_{i t}$ & 0.8284 & 1.0000 & 0.8239 & 1.0000 & 0.8471 & 1.0000 \\
\hline SALE $_{i t}$ & 11.9114 & 11.8611 & 11.8673 & 11.8331 & 12.0906 & 11.9952 \\
\hline $\mathrm{OG}_{\mathrm{it}} * \mathrm{SALE}_{\mathrm{it}}$ & 0.4906 & 0.0000 & 0.0611 & 0.0000 & 2.2375 & 0.0000 \\
\hline ADJ_INC ${ }_{i t}$ & 0.0148 & 0.0521 & 0.0097 & 0.0519 & 0.0356 & 0.0527 \\
\hline $\mathrm{CFO}_{\text {it }}$ & 0.0342 & 0.0586 & 0.0303 & 0.0577 & 0.0500 & 0.0614 \\
\hline $\mathrm{CFO}_{\text {it-1 }}$ & 0.0317 & 0.0585 & 0.0276 & 0.0574 & 0.0481 & 0.0616 \\
\hline$\Delta \mathrm{AR}_{\mathrm{it}}$ & 0.0139 & 0.0052 & 0.0147 & 0.0057 & 0.0106 & 0.0034 \\
\hline
\end{tabular}




\begin{tabular}{|c|c|c|c|c|c|c|}
\hline$\Delta \mathrm{INV}_{\text {it }}$ & 0.0088 & 0.0000 & 0.0093 & 0.0000 & 0.0066 & 0.0000 \\
\hline$\Delta \mathrm{AP}_{\mathrm{it}}$ & 0.0074 & 0.0000 & 0.0077 & 0.0000 & 0.0062 & 0.0000 \\
\hline $\mathrm{DEP}_{\mathrm{it}}$ & 0.0360 & 0.0325 & 0.0351 & 0.0319 & 0.0397 & 0.0349 \\
\hline $\mathrm{AMORT}_{\text {it }}$ & 0.0027 & 0.0000 & 0.0030 & 0.0000 & 0.0018 & 0.0000 \\
\hline OTHER $_{\text {it }}$ & -0.0222 & -0.0093 & -0.0243 & -0.0103 & -0.0137 & -0.0060 \\
\hline $\mathrm{ACC}_{\mathrm{it}}$ & -0.0465 & -0.0396 & -0.0468 & -0.0390 & -0.0456 & -0.0412 \\
\hline $\mathrm{ACC}_{\mathrm{it}-1}$ & -0.0404 & -0.0371 & -0.0405 & -0.0364 & -0.0401 & -0.0395 \\
\hline $\mathrm{RET}_{\text {it }}$ & 0.0433 & 0.0353 & 0.0424 & 0.0343 & 0.0471 & 0.0394 \\
\hline $\mathrm{EP}_{\text {it }}$ & 1.0416 & 0.9102 & 1.0858 & 0.9469 & 0.8617 & 0.7289 \\
\hline $\mathrm{CAP}_{\text {it }}$ & 5.0445 & 4.9104 & 4.9936 & 4.8763 & 5.2513 & 5.0949 \\
\hline $\mathrm{AGE}_{\mathrm{it}}$ & 2.2993 & 2.3026 & 2.2563 & 2.1972 & 2.4739 & 2.4849 \\
\hline $\mathrm{ATO}_{\text {it }}$ & 0.1744 & 0.0000 & 0.1765 & 0.0000 & 0.1657 & 0.0118 \\
\hline ADJ_TA $A_{i t}(\$$ bill. $)$ & 2.3406 & 0.1538 & 1.3857 & 0.1430 & 6.2249 & 0.2369 \\
\hline
\end{tabular}

Variable definitions are provided in Appendix A.

\subsection{Depreciation Choice Results}

Table 3 reports the probit regression results for Equation (1). As expected, the coefficients on $\mathrm{RD}_{\mathrm{it}}, \mathrm{LABOR}_{\mathrm{it}}, \mathrm{MFG}_{\mathrm{it}}{ }^{*} \mathrm{COGS}_{\mathrm{it}}, \mathrm{NMFG}_{\mathrm{it}}{ }^{*} \mathrm{COGS}_{\mathrm{it}}, \mathrm{ADV}_{\mathrm{it}}$, and $\mathrm{LEVMV}_{\mathrm{it}}$ are all negative and significant ( $\mathrm{p}$-values $\leq 0.017$ ). Also, as expected, the coefficients on DPEN $\mathrm{it}_{\text {it }}$ and $\mathrm{OG}_{\mathrm{it}}{ }^{*} \mathrm{SALE}_{\mathrm{it}}$ are both positive and significant ( $\mathrm{p}$-value $<0.001$ ). The coefficients on $\mathrm{DUR}_{\mathrm{it}}, \mathrm{DROA}_{\mathrm{it}}$, and $\mathrm{SALE}_{i t}$ are all insignificant ( $\mathrm{p}$-values $>0.10$ ), while the coefficient on $\mathrm{NP}_{\mathrm{it}}$ is significant in the opposite direction ( $\mathrm{p}$-value $<0.001$ ) (Note 10). The pseudo $\mathrm{R}^{2}$ is 13.57 percent and the model is highly significant ( $\mathrm{p}$-value $<0.001$ ). On balance, these results are quite comparable to the results in Bowen et al. (1995). Overall, the results for our sample in Tables 1, 2 and 3 are also comparable to similar tables in Jackson et al. (2009).

$$
\begin{aligned}
& \mathrm{CHOICE}_{\mathrm{it}}=\lambda_{0}+\lambda_{1} \mathrm{DUR}_{\mathrm{it}}+\lambda_{2} \mathrm{RD}_{\mathrm{it}}+\lambda_{3} \mathrm{LABOR}_{\mathrm{it}}+\lambda_{4} \mathrm{DPEN}_{\mathrm{it}}+\lambda_{5}\left(\mathrm{MFG}_{\mathrm{it}} * \mathrm{COGS}_{\mathrm{it}}\right) \\
& +\lambda_{6}\left(\mathrm{NMFG}_{\mathrm{it}} * \mathrm{COGS}_{\mathrm{it}}\right)+\lambda_{7} \mathrm{NP}_{\mathrm{it}}+\lambda_{8} \mathrm{ADV}_{\mathrm{it}}+\lambda_{9} \mathrm{LEVMV}_{\mathrm{it}}+\lambda_{10} \mathrm{DROA}_{\mathrm{it}} \\
& +\lambda_{11} \mathrm{SALE}_{\mathrm{it}}+\lambda_{12}\left(\mathrm{OG}_{\mathrm{it}} * \mathrm{SALE}_{\mathrm{it}}\right)+\varepsilon_{\mathrm{it}}
\end{aligned}
$$


Table 3. First stage probit regression of depreciation choice on economic determinants

\begin{tabular}{|c|c|c|c|c|}
\hline & Pred & & & \\
\hline Variables & sign & Coefficient & Z-statistic & $\mathrm{p}$-value \\
\hline Intercept & $?$ & -0.182 & -1.24 & 0.214 \\
\hline DUR $_{\text {it }}$ & - & 0.051 & 1.02 & 0.309 \\
\hline $\mathrm{RD}_{\text {it }}$ & - & -2.437 & -8.29 & $<0.001$ \\
\hline $\mathrm{LABOR}_{\mathrm{it}}$ & - & -0.729 & -9.10 & $<0.001$ \\
\hline $\mathrm{DPEN}_{\mathrm{it}}$ & + & 0.169 & 3.62 & $<0.001$ \\
\hline $\mathrm{MFG}_{\mathrm{it}} * \mathrm{COGS}_{\mathrm{it}}$ & - & -0.146 & -2.40 & 0.017 \\
\hline $\mathrm{NMFG}_{\mathrm{it}} * \mathrm{COGS}_{\mathrm{it}}$ & - & -0.155 & -3.53 & $<0.001$ \\
\hline $\mathrm{NP}_{\text {it }}$ & - & 1.236 & 4.67 & $<0.001$ \\
\hline $\mathrm{ADV}_{\text {it }}$ & - & -2.046 & -2.77 & 0.006 \\
\hline $\mathrm{LEVMV}_{\text {it }}$ & - & -0.085 & -3.53 & $<0.001$ \\
\hline $\mathrm{DROA}_{i t}$ & - & -0.025 & -0.82 & 0.410 \\
\hline SALE $_{i t}$ & + & -0.016 & -1.38 & 0.169 \\
\hline $\mathrm{OG}_{\mathrm{it}} * \mathrm{SALE}_{\mathrm{it}}$ & + & 0.149 & 12.55 & $<0.001$ \\
\hline Observations & & & & 56,303 \\
\hline Pseudo $\mathrm{R}^{2}(\%)$ & & & & 13.57 \\
\hline Model p-value & & & & $<0.001$ \\
\hline
\end{tabular}

Variables are defined in Appendix A. Significance tests use standard errors clustered by firm.

\subsection{Depreciation Choice and Future Earnings Results}

Regression results for testing whether accelerated depreciation choice is associated with higher future performance are provided in Table 4 (future earnings) and Table 5 (future operating cash flows). Table 4 reveals that the coefficient on $\mathrm{CHOICE}_{\text {it }}$ in Equation (2) is positive and statistically significant when the dependent variable is $\mathrm{ADJ}_{-} \mathrm{INC}_{\mathrm{it}+1}$ (coefficient $=0.032$, t-statistic $=10.54, \mathrm{p}$-value $<0.001)$, ADJ_INC $\mathrm{It}_{\mathrm{it}+2}($ coefficient $=0.048, \mathrm{t}$-statistic $=$ $11.58, \mathrm{p}$-value $<0.001)$, and ADJ_INC $\mathrm{It}_{\mathrm{t}+3}($ coefficient $=0.061$, t-statistic $=12.01, \mathrm{p}$-value $<$ $0.001)$.

The interpretation of the coefficient on $\mathrm{CHOICE}_{\mathrm{it}}$ is that adjusted income, expressed as a percentage of adjusted total assets, is reliably higher in periods $t+1, t+2$, and $t+3$, respectively, 
for firms that use accelerated depreciation compared with those firms that use straight-line depreciation. These findings are consistent with our hypothesis that the use of accelerated depreciation is correlated with higher future performance (i.e., proxied by future earnings).

$$
\begin{aligned}
\text { ADJ_INC }_{\text {it }+\mathrm{j}} & =\beta_{0}+\beta_{1} \mathrm{CHOICE}_{\mathrm{it}}+\beta_{2} \mathrm{CFO}_{\mathrm{it}}+\beta_{3} \Delta \mathrm{AR}_{\mathrm{it}}+\beta_{4} \Delta \mathrm{INV}_{\mathrm{it}}+\beta_{5} \Delta \mathrm{AP}_{\mathrm{it}} \\
& +\beta_{6} \mathrm{DEP}_{\mathrm{it}}+\beta_{7} \mathrm{AMORT}_{\mathrm{it}}+\beta_{8} \mathrm{OTHER}_{\mathrm{it}}+\beta_{9} \mathrm{CFO}_{\mathrm{it}-1}+\beta_{10} \mathrm{ACC}_{\mathrm{it}-1} \\
& +\beta_{11} \mathrm{RET}_{\mathrm{it}}+\beta_{12} \mathrm{EP}_{\mathrm{it}}+\beta_{13} \mathrm{CAP}_{\mathrm{it}}+\beta_{14} \mathrm{AGE}_{\mathrm{it}}+\beta_{15} \mathrm{ATO}_{\mathrm{it}} \\
& +\beta_{16} \mathrm{MILLS}_{\mathrm{it}}+\varepsilon_{\mathrm{it}}
\end{aligned}
$$

Table 4. Second stage OLS regressions of future earnings on depreciation choice and economic determinants

Panel A. ADJ_INC $\mathrm{it}_{+1}$

\begin{tabular}{lllll}
\hline Variables & Predicted sign & Coeff. & t-stat. & p-value \\
\hline Intercept & $?$ & -0.068 & -25.31 & $<0.001$ \\
\hline Test variable & & & & \\
\hline \multicolumn{1}{c}{ CHOICE $_{\mathrm{it}}$} & + & 0.032 & 10.54 & $<0.001$ \\
\hline
\end{tabular}

Earnings decomposition

from Barth et al. (2001)

\begin{tabular}{ccccc}
\hline $\mathrm{CFO}_{\text {it }}$ & + & 0.692 & 61.80 & $<0.001$ \\
\hline$\Delta \mathrm{AR}_{\mathrm{it}}$ & + & 0.548 & 31.41 & $<0.001$ \\
\hline$\Delta \mathrm{INV}_{\mathrm{it}}$ & + & 0.497 & 23.85 & $<0.001$ \\
\hline$\Delta \mathrm{AP}_{\mathrm{it}}$ & - & -0.556 & -22.88 & $<0.001$ \\
\hline $\mathrm{DEP}_{\mathrm{it}}$ & + & 0.155 & 4.41 & $<0.001$ \\
\hline $\mathrm{AMORT}_{\mathrm{it}}$ & + & -1.135 & -9.79 & $<0.001$ \\
\hline OTHER $_{\text {it }}$ & + & 0.358 & 26.27 & $<0.001$ \\
\hline
\end{tabular}

Additional lags

\begin{tabular}{ccccc}
\hline $\mathrm{CFO}_{\text {it-1 }}$ & + & 0.154 & 15.26 & $<0.001$ \\
\hline $\mathrm{ACC}_{\text {it-1 }}$ & + & 0.107 & 11.27 & $<0.001$ \\
\hline $\begin{array}{l}\text { Other } \\
\text { determinants }\end{array}$ & economic & & & \\
\hline RET $_{\text {it }}$ & + & 0.009 & 10.77 & $<0.001$ \\
\hline
\end{tabular}




\begin{tabular}{ccccc}
\hline $\mathrm{EP}_{\text {it }}$ & - & -0.026 & -2.26 & 0.024 \\
\hline $\mathrm{CAP}_{\mathrm{it}}$ & + & 0.001 & 5.76 & $<0.001$ \\
\hline $\mathrm{AGE}_{\mathrm{it}}$ & + & 0.010 & 17.62 & $<0.001$ \\
\hline $\mathrm{ATO}_{\mathrm{it}}$ & + & 0.013 & 15.19 & $<0.001$ \\
\hline MILLS $_{\mathrm{it}}$ & $?$ & -0.016 & -8.89 & $<0.001$ \\
\hline Observations & & & & 56,303 \\
\hline Adjusted R & & & 56.09 \\
\hline Model p-value & & & & $<0.001$ \\
\hline
\end{tabular}

Panel B. ADJ_INC ${ }_{\mathrm{it}+2}$

\begin{tabular}{|c|c|c|c|c|}
\hline Variables & Predicted sign & Coeff. & t-stat. & $\mathrm{p}$-value \\
\hline Intercept & $?$ & -0.080 & -21.07 & $<0.001$ \\
\hline \multicolumn{5}{|l|}{ Test variable } \\
\hline CHOICEit & + & 0.048 & 11.58 & $<0.001$ \\
\hline \multicolumn{5}{|c|}{$\begin{array}{l}\text { Earnings decomposition from } \\
\text { Barth et al. (2001) }\end{array}$} \\
\hline CFOit & + & 0.532 & 42.05 & $<0.001$ \\
\hline$\Delta$ ARit & + & 0.357 & 18.08 & $<0.001$ \\
\hline$\Delta \mathrm{INVit}$ & + & 0.350 & 14.66 & $<0.001$ \\
\hline$\Delta$ APit & - & -0.429 & -15.30 & $<0.001$ \\
\hline DEPit & + & 0.350 & 7.70 & $<0.001$ \\
\hline AMORTit & + & -0.317 & -2.17 & 0.030 \\
\hline OTHERit & + & 0.246 & 15.42 & $<0.001$ \\
\hline
\end{tabular}

Additional lags 


\begin{tabular}{ccccc}
\hline CFOit-1 & + & 0.175 & 15.63 & $<0.001$ \\
\hline ACCit-1 & + & 0.124 & 11.48 & $<0.001$ \\
\hline
\end{tabular}

Other economic determinants

\begin{tabular}{ccccc}
\hline RETit & + & -0.002 & -1.58 & 0.115 \\
\hline EPit & - & -0.042 & -2.71 & 0.007 \\
\hline CAPit & + & 0.002 & 5.13 & $<0.001$ \\
\hline AGEit & + & 0.011 & 14.56 & $<0.001$ \\
\hline ATOit & + & 0.016 & 14.04 & $<0.001$ \\
\hline MILLSit & $?$ & -0.026 & -10.36 & $<0.001$ \\
\hline Observations & & & & 49,175 \\
\hline Adjusted R2 $(\%)$ & & & & $<0.85$ \\
\hline Model p-value & & & & $<.001$ \\
\hline
\end{tabular}

Panel C. ADJ_INC ${ }_{i t+3}$

\begin{tabular}{|c|c|c|c|c|}
\hline Variables & Predicted sign & Coeff. & t-stat. & $\mathrm{p}$-value \\
\hline Intercept & $?$ & -0.084 & -18.24 & $<0.001$ \\
\hline \multicolumn{5}{|l|}{ Test variable } \\
\hline CHOICEit & + & 0.061 & 12.01 & $<0.001$ \\
\hline \multicolumn{5}{|c|}{$\begin{array}{l}\text { Earnings decomposition from } \\
\text { Barth et al. (2001) }\end{array}$} \\
\hline CFOit & + & 0.428 & 29.95 & $<0.001$ \\
\hline$\Delta$ ARit & + & 0.290 & 14.43 & $<0.001$ \\
\hline$\Delta \mathrm{INVit}$ & + & 0.268 & 10.60 & $<0.001$ \\
\hline
\end{tabular}




\begin{tabular}{lcccc}
\hline$\Delta$ APit & - & -0.386 & -12.64 & $<0.001$ \\
\hline DEPit & + & 0.402 & 7.71 & $<0.001$ \\
\hline AMORTit & + & 0.330 & 1.93 & 0.054 \\
\hline OTHERit & + & 0.215 & 11.96 & $<0.001$ \\
\hline
\end{tabular}

Additional lags

\begin{tabular}{ccccc}
\hline CFOit-1 & + & 0.190 & 15.76 & $<0.001$ \\
\hline ACCit-1 & + & 0.139 & 11.49 & $<0.001$ \\
\hline
\end{tabular}

Other economic determinants

\begin{tabular}{ccccc}
\hline RETit & + & -0.006 & -5.53 & $<0.001$ \\
\hline EPit & - & -0.045 & -2.59 & 0.010 \\
\hline CAPit & + & 0.002 & 5.50 & $<0.001$ \\
\hline AGEit & + & 0.011 & 11.81 & $<0.001$ \\
\hline ATOit & + & 0.018 & 12.58 & $<0.001$ \\
\hline MILLSit & $?$ & -0.034 & -10.90 & $<0.001$ \\
\hline Observations & & & & 42,794 \\
\hline Adjusted R2 $(\%)$ & & & & 34.11 \\
\hline Model p-value & & & & $<0.001$
\end{tabular}

Variables are defined in Appendix A. Significance tests use standard errors clustered by firm.

Table 4 shows that the coefficients on the control variables in Equation (2) are significant in the predicted directions for earnings horizons of one, two, and three years ahead ( $p$-values < 0.001), except for $\mathrm{AMORT}_{i t}$ and $\mathrm{RET}_{\mathrm{it}}$. The sign of the coefficient on $\mathrm{AMORT}_{\text {it }}$ is significant in the opposite direction for earnings horizons of $t+1$ and $t+2$ ( $p$-values $\leq 0.030)$. The sign of the coefficient on $\mathrm{RET}_{\text {it }}$ is insignificant for the earnings horizon of $t+2(p$-value $=0.115)$, while the sign of the coefficient on $\mathrm{RET}_{\mathrm{it}}$ is significant in the opposite direction for the earnings horizon of $t+3$ ( $p$-value $<0.001$ ) (Note 11). The coefficient on the self-selection 
variable, MILLS ${ }_{\mathrm{it}}$, in Table 4 is highly significant ( $\mathrm{p}$-value $<0.001$ ), which verifies the appropriateness of using the two stage Heckman procedure. Finally, the explanatory power of the models is substantial, ranging from 34.11 percent (year $t+3$ ) to 56.09 percent (year $t+1$ ).

\subsection{Depreciation Choice and Future Cash Flows Results}

Table 5 reveals that the coefficient on $\mathrm{CHOICE}_{\mathrm{it}}$ in Equation (2) is positive and highly significant when the dependent variable is $\mathrm{CFO}_{\mathrm{it}+1}$ (coefficient $=0.038, \mathrm{t}$-statistic $=15.53$, p-value $<0.001), \mathrm{CFO}_{\mathrm{it}+2}$ (coefficient $=0.047$, t-statistic $=13.56$, p-value $\left.<0.001\right)$, and $\mathrm{CFO}_{\mathrm{it}+3}$ (coefficient $=0.056, \mathrm{t}$-statistic $=12.92$, p-value $<0.001$ ). The interpretation of the coefficient on $\mathrm{CHOICE}_{\mathrm{it}}$ is that operating cash flows, expressed as a percentage of adjusted total assets, are reliably higher in periods $t+1, t+2$, and $t+3$, respectively, for firms that use accelerated depreciation compared with those firms that use straight-line depreciation. These findings add further support to our hypothesis that the use of accelerated depreciation is correlated with higher firm performance (i.e., proxied by future cash flows).

$$
\begin{aligned}
\mathrm{CFO}_{\mathrm{it}+\mathrm{j}} & =\beta_{0}+\beta_{1} \mathrm{CHOICE}_{\mathrm{it}}+\beta_{2} \mathrm{CFO}_{\mathrm{it}}+\beta_{3} \Delta \mathrm{AR}_{\mathrm{it}}+\beta_{4} \Delta \mathrm{INV}_{\mathrm{it}}+\beta_{5} \Delta \mathrm{AP}_{\mathrm{it}} \\
& +\beta_{6} \mathrm{DEP}_{\mathrm{it}}+\beta_{7} \mathrm{AMORT}_{\mathrm{it}}+\beta_{8} \mathrm{OTHER}_{\mathrm{it}}+\beta_{9} \mathrm{CFO}_{\mathrm{it}-1}+\beta_{10} \mathrm{ACC}_{\mathrm{it}-1} \\
& +\beta_{11} \mathrm{RET}_{\mathrm{it}}+\beta_{12} \mathrm{EP}_{\mathrm{it}}+\beta_{13} \mathrm{CAP}_{\mathrm{it}}+\beta_{14} \mathrm{AGE}_{\mathrm{it}}+\beta_{15} \mathrm{ATO}_{\mathrm{it}} \\
& +\beta_{16} \mathrm{MILLS}_{\mathrm{it}}+\varepsilon_{\mathrm{it}}
\end{aligned}
$$

\begin{tabular}{|c|c|c|c|c|}
\hline Variables & Predicted sign & Coeff. & t-stat. & $\mathrm{p}$-value \\
\hline Intercept & $?$ & -0.035 & -16.67 & $<0.001$ \\
\hline \multicolumn{5}{|l|}{ Test variable } \\
\hline $\mathrm{CHOICE}_{\mathrm{it}}$ & + & 0.038 & 15.53 & $<0.001$ \\
\hline \multicolumn{5}{|l|}{$\begin{array}{l}\text { Earnings decomposition from } \\
\text { Barth et al. (2001) }\end{array}$} \\
\hline $\mathrm{CFO}_{\text {it }}$ & + & 0.578 & 68.02 & $<0.001$ \\
\hline$\Delta \mathrm{AR}_{\mathrm{it}}$ & + & 0.411 & 30.20 & $<0.001$ \\
\hline$\Delta \mathrm{INV}_{\text {it }}$ & + & 0.245 & 14.67 & $<0.001$ \\
\hline$\Delta \mathrm{AP}_{\mathrm{it}}$ & - & -0.502 & -25.87 & $<0.001$ \\
\hline $\mathrm{DEP}_{\mathrm{it}}$ & + & 0.368 & 15.17 & $<0.001$ \\
\hline $\mathrm{AMORT}_{\mathrm{it}}$ & + & 0.465 & 6.75 & $<0.001$ \\
\hline OTHER $_{\text {it }}$ & + & 0.145 & 15.18 & $<0.001$ \\
\hline \multicolumn{5}{|l|}{ Additional lags } \\
\hline $\mathrm{CFO}_{\text {it-1 }}$ & + & 0.179 & 23.69 & $<0.001$ \\
\hline
\end{tabular}

Table 5. Second stage OLS regressions of future cash flows on depreciation choice and economic determinants

Panel A. $\mathrm{CFO}_{\text {it+1 }}$ 
$\mathrm{ACC}_{\mathrm{it}-1}$

$+$

$0.070 \quad 9.86$

$<0.001$

Other economic determinants

\begin{tabular}{ccccc}
\hline $\mathrm{RET}_{\text {it }}$ & + & -0.003 & -4.16 & $<0.001$ \\
\hline $\mathrm{EP}_{\mathrm{it}}$ & - & -0.093 & -9.93 & $<0.001$ \\
\hline $\mathrm{CAP}_{\mathrm{it}}$ & + & 0.002 & 9.79 & $<0.001$ \\
\hline $\mathrm{AGE}_{\mathrm{it}}$ & + & 0.004 & 10.38 & $<0.001$ \\
\hline $\mathrm{ATO}_{\mathrm{it}}$ & + & 0.009 & 12.90 & $<0.001$ \\
\hline MILLS & $?$ & -0.022 & -14.46 & $<0.001$ \\
\hline Observations & & & & 56,303 \\
\hline Adjusted R & & & & 58.98 \\
\hline Model p-value & & & & $<0.001$
\end{tabular}

Panel B. $\mathrm{CFO}_{\mathrm{it}+2}$

\begin{tabular}{|c|c|c|c|c|}
\hline Variables & Predicted sign & Coeff. & t-stat. & $\mathrm{p}$-value \\
\hline Intercept & $?$ & -0.044 & -15.34 & $<0.001$ \\
\hline \multicolumn{5}{|l|}{ Test variable } \\
\hline CHOICEit & + & 0.047 & 13.56 & $<0.001$ \\
\hline \multicolumn{5}{|c|}{$\begin{array}{l}\text { Earnings decomposition from } \\
\text { Barth et al. (2001) }\end{array}$} \\
\hline CFOit & + & 0.467 & 48.81 & $<0.001$ \\
\hline$\Delta$ ARit & + & 0.296 & 20.65 & $<0.001$ \\
\hline$\Delta$ INVit & + & 0.252 & 13.88 & $<0.001$ \\
\hline$\Delta \mathrm{APit}$ & - & -0.320 & -15.02 & $<0.001$ \\
\hline DEPit & + & 0.449 & 13.34 & $<0.001$ \\
\hline AMORTit & + & 0.595 & 6.10 & $<0.001$ \\
\hline OTHERit & + & 0.135 & 11.80 & $<0.001$ \\
\hline
\end{tabular}


Additional lags

\begin{tabular}{lllll}
\hline CFOit-1 & + & 0.183 & 22.15 & $<0.001$ \\
\hline ACCit-1 & + & 0.077 & 10.02 & $<0.001$ \\
\hline
\end{tabular}

Other economic determinants

\begin{tabular}{ccccc}
\hline RETit & + & -0.003 & -4.89 & $<0.001$ \\
\hline EPit & - & -0.075 & -6.22 & $<0.001$ \\
\hline CAPit & + & 0.003 & 10.96 & $<0.001$ \\
\hline AGEit & + & 0.005 & 8.03 & $<0.001$ \\
\hline ATOit & + & 0.011 & 11.78 & $<0.001$ \\
\hline MILLSit & $?$ & -0.028 & -13.00 & $<0.001$ \\
\hline Observations & & & & 49,175 \\
\hline Adjusted R2 $(\%)$ & & & & 46.76 \\
\hline Model p-value & & & & $<0.001$ \\
\hline
\end{tabular}

Panel C. $\mathrm{CFO}_{\mathrm{it}+3}$

\begin{tabular}{lllll}
\hline Variables & Predicted sign & Coeff. & t-stat. & p-value \\
\hline Intercept & $?$ & -0.048 & -13.57 & $<0.001$ \\
\hline Test variable & & & & \\
\hline CHOICEit & + & 0.056 & 12.92 & $<0.001$ \\
\hline $\begin{array}{l}\text { Earnings decomposition } \\
\text { Barth et al. (2001) }\end{array}$ & & & & \\
\hline CFOit & + & 0.395 & 36.57 & $<0.001$ \\
\hline \multicolumn{1}{c}{ fromit } & + & 0.268 & 16.68 & $<0.001$ \\
\hline
\end{tabular}




\begin{tabular}{lcccc}
\hline$\Delta$ INVit & + & 0.204 & 10.18 & $<0.001$ \\
\hline$\Delta$ APit & - & -0.290 & -12.34 & $<0.001$ \\
\hline DEPit & + & 0.470 & 11.63 & $<0.001$ \\
\hline AMORTit & + & 0.653 & 5.22 & $<0.001$ \\
\hline OTHERit & + & 0.111 & 8.45 & $<0.001$ \\
\hline
\end{tabular}

Additional lags

\begin{tabular}{ccccc}
\hline CFOit-1 & + & 0.179 & 19.46 & $<0.001$ \\
\hline ACCit-1 & + & 0.088 & 9.91 & $<0.001$ \\
\hline
\end{tabular}

Other economic determinants

\begin{tabular}{ccccc}
\hline RETit & + & -0.005 & -6.12 & $<0.001$ \\
\hline EPit & - & -0.061 & -4.46 & $<0.001$ \\
\hline CAPit & + & 0.004 & 11.15 & $<0.001$ \\
\hline AGEit & + & 0.004 & 5.92 & $<0.001$ \\
\hline ATOit & + & 0.012 & 10.43 & $<0.001$ \\
\hline MILLSit & $?$ & -0.033 & -12.57 & $<0.001$ \\
\hline Observations & & & & 42,794 \\
\hline Adjusted R2 $(\%)$ & & & & 39.60 \\
\hline Model p-value & & & & $<0.001$
\end{tabular}

Variables are defined in Appendix A. Significance tests use standard errors clustered by firm.

Table 5 shows that the coefficients on the control variables in Equation (2) are significant in the predicted directions for operating cash flow horizons of one, two, and three years ahead (p-values < 0.001), except for RET it $_{\text {(Note 12). The sign of the coefficient on RET }}$ it is significant in the opposite direction for each of the cash flow horizons considered (p-values < 0.001), which suggests that evidence in prior research that stock returns foreshadow higher 
future earnings does not hold for operating cash flows. The coefficient on the self-selection variable, MILLS $_{\mathrm{it}}$, in Table 5 is highly significant ( $\mathrm{p}$-value $<0.001$ ), which verifies the appropriateness of using the two stage Heckman procedure. Finally, the explanatory power of the models is substantial, ranging from 39.60 percent (year $t+3$ ) to 58.98 percent (year $t+1)$.

\section{Supplemental Analysis}

\subsection{Depreciation Choice and Future Losses}

Table 2 indicates that loss years are much more common for straight-line firms than for accelerated firms. Losses occur in 9.24 percent of our sample firm years, but this frequency varies dramatically between straight-line firms and accelerated firms. For straight-line firms, losses occur in 10.35 percent of the firm years. However, for accelerated firms, losses occur in only 4.26 percent of the firm years. Given this difference, we explore whether firms' depreciation choices foreshadow future losses.

To address this question, we re-estimate Equation (2) with an alternative dependent variable, LOSS $_{\text {it. }}$ Because of the coding of this alternative dependent variable, the expected signs of the variables in Equation (2) by design will switch. In untabulated results, we find the coefficient on $\mathrm{CHOICE}_{\mathrm{it}}$ is negative and significant when the dependent variable is LOSS $_{\mathrm{it}+1}$ (coefficient $=-0.680, \mathrm{t}$-statistic $=-6.51, \mathrm{p}$-value $<0.001)$, LOSS $_{\mathrm{it}+2}$ (coefficient $=-0.726$, $\mathrm{t}$-statistic $=-6.12, \mathrm{p}$-value $<0.001)$, and $\operatorname{LOSS}_{\mathrm{it}+3}($ coefficient $=-0.885, \mathrm{t}$-statistic $=6.54$, $\mathrm{p}$-value $<0.001$ ) (Note 13). These results imply that the use of accelerated depreciation foreshadows a lower incidence of future losses than the use of straight-line depreciation.

\subsection{Mix of Assets Using Alternative Depreciation Methods}

Our main sample categorizes an accelerated depreciation observation as one in which the Compustat footnote code suggests that accelerated depreciation is used for some or all of their depreciable assets. We drop from the analysis those observations that use both methods. That is, we test future performance of the group of accelerated depreciation (only) observations compared to with the straight-line depreciation (only) observations. The conclusions on the positive association of the choice variable to future performance are robust to this reduced sample.

\section{Conclusions}

This study provides evidence that firms' depreciation choice is associated with future earnings and cash flows for horizons of one, two, and three years ahead. The suggestion that asymmetric information is the only factor in depreciation choice would not be justified. We make no such claim. The evidence does, however, indicate that information asymmetry can contribute to our understanding of accounting choices made by managers.

A few caveats are worth noting as well as some directions for future research. First, in our research design, we attempted to control for a great deal of heterogeneity across firms. It is possible that our results could be explained (in part or in whole) due to our inability to consider such differences or due to poorly measured proxies employed in our controls. Second, the data sources used in the study for firms that choose accelerated depreciation lack 
sufficient detail to consider the levels of asset classes subject to alternative depreciation methods. Future research could extend our study using data (likely hand collected) on the levels of asset classes subject to different depreciation methods. Third, we did not consider the variation in information asymmetry in our tests. A powerful test to extend our study might incorporate a reliable proxy for the variation in asymmetric information to investigate whether the signaling we document in depreciation choice is positively correlated with the degree of information asymmetry.

In sum, our findings are consistent with a large body of theoretical and empirical research in corporate finance and economics on signaling theory. We offer empirical evidence that accounting choices can be explained (in part) by incentives to signal, most likely due to the problem of adverse selection.

\section{Acknowledgement}

We thank Erin Hamilton, Scott Jackson, Steven Jackson, Srini Sankaraguruswamy, Kelvin Liu, Elaine Mauldin, Linda Quick, Susan Watts, Kaye Newberry, Wayne Thomas, and workshop participants at the 2012 American Accounting Association annual meeting, University of Alabama, and Kennesaw State University for helpful comments. All data are publicly available.

\section{References}

Akerlof, G. A. (1970). The market for "lemons": quality uncertainty and the market mechanism. Quarterly Journal of Economics, 84(3), 488-500.

Anthony, J., \& Ramesh, K. (1992). Association between accounting performance measures and stock prices: A test of the life-cycle hypothesis. Journal of Accounting and Economics, 15(2-3), 203-228.

Archibald, T. (1972). Stock market reaction to the depreciation switch-back. The Accounting Review, 47(1), 22-30.

Bagnoli, M.., \& Watts, S. (2005). Conservative accounting choices. Management Science, 51(5), 768-801.

Barclay, M., \& Smith, C. Jr. (1988). Corporate payout policy: Cash dividends versus open-market repurchases. Journal of Financial Economics, 22(1), 61-82.

Barth, M., Cram, D., \& Nelson, K. (2001). Accruals and the prediction of future cash flows. The Accounting Review, 76(1), 27-58.

Barton, J. (2001). Does the use of financial derivatives affect earnings management decisions? The Accounting Review, 76(1), 1-26.

Bartov, E. (1993). The timing of asset sales and earnings manipulation. The Accounting Review, 68(4), 840-855.

Bartov, E., Givoly, D., \& Hayn, C. (2002). The rewards to meeting or beating earnings expectations. Journal of Accounting and Economics, 33(2), 173-204. 


\section{Macrothink}

International Journal of Accounting and Financial Reporting

ISSN 2162-3082 2019, Vol. 9, No. 1

Beaver, W., \& Dukes, R. (1973). Interperiod tax allocation and $\delta$-depreciation methods: Some empirical results. The Accounting Review, 48(3), 549-559.

Beaver, W., Lambert, R., \& Morse, D. (1980). The information content of security prices. Journal of Accounting and Economics, 2(1), 3-28.

Bhojraj, S., \& Libby, R. (2005). Capital market pressure, disclosure frequency-induced earnings/cash flow conflict, and managerial myopia. The Accounting Review, 80(1), 1-20.

Black, E. (1998). Life-cycle impacts on the incremental value-relevance of earnings and cash flow measures. Journal of Financial Statement Analysis, 4(1), 40-56.

Bowen, R., DuCharme, L., \& Shores, D. (1995). Stakeholders' implicit claims and accounting method choice. Journal of Accounting and Economics, 20(3), 255-295.

Brennan, M. (1990). Latent assets. The Journal of Finance, 45(3), 709-730.

Brennan, M., \& Copeland, T. (1988). Stock splits, stock prices, and transaction costs. Journal of Financial Economics, 22(1), 83-101.

Brown, L. (2001). A temporal analysis of earnings surprises: Profits versus losses. Journal of Accounting Research, 39(2), 221-241.

Brown, L., \& Caylor, M. (2005). A temporal analysis of quarterly earnings thresholds: Propensities and valuation consequences. The Accounting Review, 80(2), 423-440.

Bushee, B. (1998). The influence of institutional investors on myopic RD investment behavior. The Accounting Review, 73(3), 305-333.

Cahan, S. (1992). The effect of antitrust investigations on discretionary accruals: A refined test of the political-cost hypothesis. The Accounting Review, 67(1), 77-95.

Christian, C., Gupta, S., Weber, G., \& Willis, E. (1994). The relation between the use of tax preparers and taxpayers' prepayment position. Journal of the American Taxation Association, 16(1), 17-40.

Christie, A., \& Zimmerman, J. (1994). Efficient and opportunistic choices of accounting procedures: Corporate control contests. The Accounting Review, 69(4), 539-566.

Cohen, D., Dey, A., \& Lys, T. (2008). Real and accruals-based earnings management in the pre- and post-Sarbanes-Oxley periods. The Accounting Review, 83(3), 757-787.

Copeland, T., \& Weston, J. (1988). Financial Theory and Corporate Policy (3rd ed.). New York, NY: Addison-Wesley.

DeAngelo, L. (1986). Accounting numbers as market valuation substitutes: A study of management buyouts of public stockholders. The Accounting Review, 61(3), 400-420.

DeAngelo, L. (1988). Managerial competition, information costs, and corporate governance. The Accounting Review, 10(1), 3-36. 


\section{Macrothink}

International Journal of Accounting and Financial Reporting

ISSN 2162-3082 2019, Vol. 9, No. 1

DeAngelo, L. (1990). Equity valuation and corporate control. The Accounting Review, 65(1), 93-112.

Dechow, P. (1994). Accounting earnings and cash flows as measures of firm performance: The role of accounting accruals. Journal of Accounting and Economics, 18(1), 3-42.

Dechow, P., Sloan, R., \& Sweeney, A. (1996). Economic consequences of accounting for stock-based compensation. Journal of Accounting Research, 34(3), 1-20.

DeFond, M., \& Jiambalvo, J. (1994). Debt covenant violation and manipulation of accruals. Journal of Accounting and Economics, 17(1-2), 145-176.

Desai, H., \& Jain, P. (1997). Long-run common stock returns following stock splits and reverse splits. Journal of Business, 70(3), 409-433.

Dichev, I., \& Tang, V. (2009). Earnings volatility and earnings predictability. Journal of Accounting and Economics, 47(1-2), 160-181.

Eisenhardt, K. (1989). Agency theory: An assessment and review. Academy of Management Review, 14(1), 57-74.

Engel, E., Hayes, R., \& Wang, X. (2003). CEO turnover and properties of accounting information. Journal of Accounting and Economics, 36(1-3), 197-226.

Espahbodi, H., Espahbodi, P., Rezaee, Z., \& Tehranian, H. (2002). Stock price reaction and value relevance of recognition versus disclosure: The case of stock-based compensation. Journal of Accounting and Economics, 33(3), 343-373.

Fan, Q. (2007). Earnings management and ownership retention for initial public offering firms: Theory and evidence. The Accounting Review, 82(1), 27-64.

Farrell, K., \& Whidbee, D. (2003). The impact of performance expectations on CEO turnover and replacement decisions. Journal of Accounting and Economics, 36(1-3), 165-196.

Fields, T., Lys, T., \& Vincent, L. (2001). Empirical research on accounting choice. Journal of Accounting and Economics, 31(1-3), 255-307.

Gaver, J., \& Gaver, K. (1998). The relation between nonrecurring accounting transactions and CEO cash compensation. The Accounting Review, 73(2), 235-253.

Graham, J., \& Harvey, C. (2001). The theory and practice of corporate finance: Evidence from the field. Journal of Financial Economics, 60(2-3), 187-243.

Graham, J., Harvey, C., \& Rajgopal, S. (2005). The economic implications of corporate financial reporting. Journal of Accounting and Economics, 40(1-3), 3-73.

Greene, W. (2003). Econometric Analysis (5th ed.). Englewood Cliffs, NJ: Prentice Hall.

Grinblatt, M., \& Hwang, C. (1989). Signaling and the pricing of new issues. The Journal of Finance, 44(2), 393-420. 


\section{MInstitute ${ }_{\text {Mnk }}^{\text {Macrothink }}$}

International Journal of Accounting and Financial Reporting

ISSN 2162-3082

2019, Vol. 9, No. 1

Gupta, S., \& Newberry, K. (1997). Determinants of variability in corporate effective tax rates: Evidence from longitudinal data. Journal of Accounting and Public Policy, 16(1), 1-34.

Healy, P., \& Palepu, K. (1988). Earnings information conveyed by dividend initiations and omissions. Journal of Financial Economics, 21(2), 149-175.

Healy, P., \& Wahlen, J. (1999). A review of the earnings management literature and its implications for standard setting. Accounting Horizons, 13(4), 365-383.

Heckman, J. (1979). The sample selection bias as a specification error. Econometrica, 47(1), 153-62.

Hirshleifer, J., \& Riley, J. (1992). The Analytics of Uncertainty and Information. New York, NY: Cambridge University Press.

Hodder, L., Hopkins, P., \& Wahlen, J. (2006). Risk-relevance of fair-value income measures for commercial banks. The Accounting Review, 81(2), 337-375.

Holthausen, R. (1981). Evidence on the effect of bond covenants and management compensation contracts on the choice of accounting techniques: The case of the depreciation switch-back. Journal of Accounting and Economics, 3(1), 73-109.

Holthausen, R., \& Leftwich, R. (1983). The economic consequences of accounting choice: Implications of costly contracting and monitoring. Journal of Accounting and Economics, 5, 77-117.

Ikenberry, D., Rankine, G., \& Stice, E. (1996). What do stock splits really signal?. Journal of Financial and Quantitative Analysis, 31(3), 357-375.

Jackson, S. (2008). The effect of firms' depreciation method choice on managers' capital investment decisions. The Accounting Review, 83(2), 351-376.

Jackson, S., Liu, X., \& Cecchini, M. (2009). Economic consequences of firms' depreciation method choice: Evidence from capital investments. Journal of Accounting and Economics, 48(1), 54-68.

Jensen, M. (2001). Corporate budgeting is broken-let's fix it. Harvard Business Review, 79(10), 94-101.

Jensen, M., \& Meckling, W. (1976). Theory of the firm: Managerial behavior, agency costs and ownership structure. Journal of Financial Economics, 3(4), 305-360.

John, K., \& Williams, J. (1985). Dividends, dilution, and taxes: A signaling equilibrium. The Journal of Finance, 40(4), 1053-1070.

Jones, J. (1991). Earnings management during import relief investigation. Journal of Accounting Research, 29(2), 193-228.

Kaplan, R., \& Roll, R. (1972). Investor evaluation of accounting information: Some empirical evidence. Journal of Business, 45(2), 225-257. 


\section{$\triangle 1$ Macrothink}

International Journal of Accounting and Financial Reporting

ISSN 2162-3082

Kasznik, R., \& McNichols, M. (2002). Does meeting earnings expectations matter? Evidence from analyst forecast revisions and share prices. Journal of Accounting Research, 40(3), 727-759.

Key, K. (1997). Political cost incentives for earnings management in the cable television industry. Journal of Accounting and Economics, 23(3), 309-337.

Kim, J., Chung, R., \& Firth, M. (2003). Auditor conservatism, asymmetric monitoring, and earnings management. Contemporary Accounting Research, 20(2), 323-359.

Kothari, S. P., \& Sloan, R. (1992). Information in prices about future earnings: Implications for earnings response coefficients. Journal of Accounting and Economics, 15(2-3), 143-171.

Lakonishok, J., \& Lev, B. (1987). Stock splits and stock dividends: Why, who, and when. The Journal of Finance, 42(4), 913-932.

Leftwich, R. (1981). Evidence on the impact of mandatory changes in accounting principles on corporate loan agreements. Journal of Accounting and Economics, 3(1), 3-36.

Leland, H., \& Pyle, D. (1977). Information asymmetries, financial structure, and financial intermediation. Journal of Finance, 32(2), 371-387.

Leuz, C., \& Verrecchia, R. (2000). The economic consequences of increased disclosure. Journal of Accounting Research, 38, Supplement, 91-124.

Louis, H., \& Robinson, D. (2005). Do managers credibly use accruals to signal private information: Evidence from the pricing of discretionary accruals around stock splits?. Journal of Accounting and Economics, 39(2), 3-36.

Maddala, G. (1983). Limited Dependent and Qualitative Variables in Econometrics. New York, NY: Cambridge University Press.

Matsunaga, S., \& Park, C. (2001). The effect of missing a quarterly earnings benchmark on the CEO's annual bonus. The Accounting Review, 76(3), 313-332.

McNichols, M., \& Dravid, A. (1990). Stock dividends, stock splits, and signaling. The Journal of Finance, 45(3), 857-879.

Milgrom, P., \& Roberts, J. (1992). Economics, Organization, and Management. Englewood Cliffs, NJ: Prentice-Hall.

Mittelstaedt, H., Nichols, W., \& Regier, P. (1995). SFAS No. 106 and benefit reductions in employer-sponsored retiree health care plans. The Accounting Review, 70(4), 535-556.

Morgan, G. (1997). Images of Organization (2nd ed.). Thousand Oaks, CA: Sage Publications.

Murphy, K. (1999). Executive Compensation. In O. Ashenfelter, \& D. Card (Eds.), Handbook of Labor Economics (Vol. 3B, pp. 2485-2563). Amsterdam, The Netherlands: North Holland. 


\section{Macrothink}

International Journal of Accounting and Financial Reporting

ISSN 2162-3082

2019, Vol. 9, No. 1

Ofer, A., \& Siegel, D. (1987). Corporate financial policy, information, and market expectations: An empirical investigation of dividends. The Journal of Finance, 42(4), 889-911.

Penman, S. (1996). The articulation of price-earnings ratios and market-to-book ratios and the evaluation of growth. Journal of Accounting Research, 34(2), 235-259.

Rankine, G., \& Stice, E. (1997). Accounting rules and the signaling properties of 20 percent stock dividends. The Accounting Review, 72(1), 23-46.

Ricks, W. (1982). Market assessment of alternative accounting methods: A review of the empirical evidence. Journal of Accounting Literature, 1, 59-102.

Riley, J. (1979). Informational equilibrium. Econometrica, 47(2), 331-359.

Ross, S. (1977). The determination of financial structure: The incentive-signaling approach. Bell Journal of Economics, 8(1), 23-40.

Roychowdhury, S. (2006). Earnings management through real activities manipulation. Journal of Accounting and Economics, 42(3), 335-370.

Seybert, N. (2010). RD capitalization and reputation-driven real earnings managment. The Accounting Review, 85(2), 671-693.

Shehata, M. (1991). Self-selection bias and the economic consequences of accounting regulation: An application of two-stage switching regression to SFAS No. 2. The Accounting Review, 66(4), 768-787.

Spence, M. (1973). Job market signaling. Quarterly Journal of Economics, 87(3), 355-379.

Subramanyam, K. (1996). The pricing of discretionary accruals. Journal of Accounting and Economics, 22(1-3), 249-281.

Sunder, S. (1997). Theory of Accounting and Control. Cincinnati, OH: South-Western Publishing.

Sweeney, A. (1994). Debt-covenant violations and managers' accounting responses. Journal of Accounting and Economics, 17(3), 281-308.

Tucker, J. (2007). Is openness penalized? Stock returns around earnings warnings. The Accounting Review, 82(4), 1055-1087.

Watts, R., \& Zimmerman, J. (1986). Positive Accounting Theory. Englewood Cliffs, NJ: Prentice-Hall.

Watts, R., \& Zimmerman, J. (1990). Positive accounting theory: A ten year perspective. The Accounting Review, 65(1), 131-156.

Xu, R., Taylor, G., \& Dugan, M. (2007). Review of real earnings management literature. Journal of Accounting Literature, 26, 195-228. 


\section{Notes}

Note 1. In a survey of CFOs, Graham et al. (2005) states that "an overwhelming majority of CFOs prefer smooth earnings (versus volatile earnings). Holding cash flows constant, volatile earnings are thought to be riskier than smooth earnings. Moreover, smooth earnings ease the analyst's task of predicting future earnings. Predictability of earnings is an over-arching concern among CFOs. The executives believe that less predictable earnings - as reflected in a missed earnings target or volatile earnings - command a risk premium in the market. A surprising $78 \%$ of the surveyed executives would give up economic value in exchange for smooth earnings" (page 5).

Note 2. Fields et al. (2001) provides a broad definition for accounting choice. They state that an "accounting choice is any decision whose primary purpose is to influence (either in form or substance) the output of the accounting system in a particular way, including not only financial statements published in accordance with GAAP, but also tax returns and regulatory filings" (page 256).

Note 3. The positive association between firms' use of accelerated depreciation and higher future cash flows cannot be attributed to taxes. This is because firms compute tax depreciation using rules prescribed by the Internal Revenue Code, while they compute financial reporting depreciation using rules prescribed by GAAP. There is no requirement that tax depreciation and financial reporting depreciation conform to one another. Thus, similar tax depreciation can occur regardless of the depreciation method chosen for financial reporting purposes for specific long-lived assets. Additionally, neither method of financial depreciation will be equivalent to tax depreciation. Thus, the choice of accelerated or straight-line offers no administrative cost savings. Furthermore, the argument of relative cost savings of straight-line over accelerated methods seems implausible given the apparent costs of lower near-term earnings and higher earnings volatility.

Note 4. Leland and Pyle (1977) has been confirmed by other studies (Grinblatt and Hwang 1989; Fan 2007).

Note 5. In our example of accounting choice, earnings satisfies the Law of Conservation of Income (Sunder 1997, p. 67) because any differences in income in one period will eventually be reversed over the life of an asset.

Note 6. Compustat annual data items are the source of financial accounting data, except for the variable CHOICEit, which is obtained from the annual footnote data in Compustat.

Note 7. Our definition of income excludes depreciation expense because we wish to purge from income the effect of firms' depreciation choice. When we add back depreciation, we express this variable on an after tax basis using the firm's effective tax rate (ETR) (i.e., we multiply depreciation expense by 1 - total income taxes / pretax income). Without this change, CHOICEit would be functionally associated with earnings. Following Gupta and Newberry (1997), we set ETR to 1 when ETR is greater than 100 percent and we set ETR to 0 when ETR is negative. Our inferences and conclusions are not affected by defining ADJ_INCit on a pre-depreciation expense basis. 


\section{Mll Macrothink}

International Journal of Accounting and Financial Reporting

ISSN 2162-3082

2019, Vol. 9, No. 1

Note 8 . We require the values of EPit be between zero and positive infinity because negative values for this variable have limited meaning. However, our inferences and conclusions are the same regardless of whether we impose this constraint on EPit.

Note 9. Also, for the variable DROAit in Equation (1), we exclude firm years in which there are fewer than ten firms within a two-digit SIC code.

Note 10. In Bowen et al. (1995), the coefficient on NPit was insignificant in each year examined and its sign was inconsistent across years.

Note 11. This finding suggests that while stock returns lead earnings for relatively short horizons (i.e., $t+1$ ), they do not lead earnings for longer horizons (i.e., $t+2$ and $t+3$ ).

Note 12. In Table 5, the signs of the coefficients on the earnings decomposition variables are the same as the signs on those variables in Barth et al. (2001).

Note 13 . We have omitted the tables for the supplemental analyses to ease the exposition.

\section{Appendix}

\section{Appendix A. Variables Used in the Study}

$\mathrm{CHOICE}_{\mathrm{it}}=$ dummy variable equal to 1 for firms that use the accelerated depreciation method for all or some of their assets, and 0 for firms that use the straight-line depreciation method;

DUR $_{\text {it }}=$ dummy variable equal to 1 for firms producing durable goods (SIC codes $150-179$, $245,250-259,283,301$, and $324-399$ ), and 0 otherwise;

$\mathrm{RD}_{\mathrm{it}}=$ research and development expense scaled by ADJ_TA $\mathrm{it}_{\mathrm{it}}(0$ if $\mathrm{RD}$ expense is missing $)$;

$\mathrm{LABOR}_{\mathrm{it}}=$ labor intensity measured as one minus the ratio of gross property, plant, and equipment to ADJ_TA $\mathrm{it}_{\mathrm{it}}(0$ if gross property, plant, and equipment is missing);

$\mathrm{DPEN}_{\mathrm{it}}=$ dummy variable equal to 1 for firms with defined benefit pension plans, identified as those firms with a non-negative value for projected pension obligation or assumed rate of return for pension benefits, and 0 otherwise;

$\mathrm{MFG}_{\mathrm{it}}=$ dummy variable equal to 1 for manufacturing firms (SIC codes 200-399), and 0 otherwise;

$\mathrm{NMFG}_{\mathrm{it}}=$ dummy variable equal to 1 for non-manufacturing firms (all SIC codes except 200-399), and 0 otherwise;

COGS $_{\mathrm{it}}=$ cost of goods sold scaled by ADJ_TA $\mathrm{it}_{\mathrm{it}}$;

$\mathrm{NP}_{\mathrm{it}}=$ notes payable scaled by ADJ_TA $\mathrm{it}_{\mathrm{it}}(0$ if notes payable is missing $)$;

$\mathrm{ADV}_{\mathrm{it}}=$ advertising expense scaled by ADJ_TA $\mathrm{A}_{\mathrm{it}}(0$ if advertising expense is missing $)$; 


\section{MlMacrothink}

International Journal of Accounting and Financial Reporting

ISSN 2162-3082

2019, Vol. 9, No. 1

$\mathrm{LEVMV}_{\text {it }}=$ ratio of long-term debt to market value of common stock ( 0 if long-term debt is missing);

$\mathrm{DROA}_{i t}=$ dummy variable equal to 1 for firms with return on assets (defined as income before extraordinary items and discontinued operations scaled by ADJ_TA ${ }_{i t}$ ) in deciles 2 through 9, where deciles are defined within two-digit SIC codes, and 0 otherwise;

$\mathrm{SALE}_{\mathrm{it}}=$ natural logarithm of net sales in thousands;

$\mathrm{OG}_{\mathrm{it}}=$ dummy variable equal to 1 for firms in the oil and gas industry (SIC codes 131 and 291), and 0 otherwise;

ADJ_INC $\mathrm{It}_{\mathrm{itj}}=$ income before extraordinary items and discontinued operations plus depreciation expense scaled by ADJ_TA it $_{\text {; }}$

$\mathrm{CFO}_{i t+j}=$ net cash flow from operating activities minus the accrual portion of extraordinary items and discontinued operations reported on the statement of cash flows scaled by ADJ_TA it $_{\text {; }}$

$\Delta \mathrm{AR}_{\mathrm{it}}=$ change in accounts receivable from the statement of cash flows scaled by ADJ_TA $\mathrm{it}_{\mathrm{it}}$ and multiplied by $-1 ; \Delta \mathrm{INV}_{\text {it }}=$ change in inventory from the statement of cash flows scaled by ADJ_TA ${ }_{\text {it }}$ and multiplied by -1 ;

$\Delta \mathrm{AP}_{\text {it }}=$ change in accounts payable and accrued liabilities from the statement of cash flows scaled by ADJ_TA it $_{\text {; }}$

$\mathrm{DEP}_{\mathrm{it}}=$ depreciation expense, computed as depreciation and amortization expense minus amortization expense (coded as 0 if amortization expense is missing) scaled by ADJ_TA $A_{i t}$;

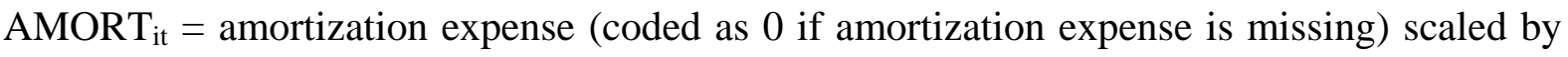
ADJ_TA ${ }_{i t}$;

$\mathrm{OTHER}_{\mathrm{it}}=$ net of all other accruals, calculated as income before extraordinary items and discontinued operations scaled by ADJ_TA $\mathrm{it}_{-}-\left(\mathrm{CFO}_{\mathrm{it}}+\Delta \mathrm{AR}_{\mathrm{it}}+\Delta \mathrm{INV}_{\mathrm{it}}-\Delta \mathrm{AP}_{\mathrm{it}}-\mathrm{DEP}_{\mathrm{it}}-\right.$ $\mathrm{AMORT}_{\mathrm{it}}$;

$\mathrm{CFO}_{\text {it- } 1}=$ net cash flow from operating activities minus the accrual portion of extraordinary items and discontinued operations reported on the statement of cash flows scaled by ADJ_TA

$\mathrm{ACC}_{\mathrm{it}-1}=$ total accruals scaled by ADJ_TA $\mathrm{it}_{\mathrm{it}}$

$\mathrm{RET}_{\text {it }}=$ stock return, computed as the year-to-year change in closing stock price divided by the prior year closing stock price;

$\mathrm{EP}_{\mathrm{it}}=$ earnings-to-price ratio if the ratio is non-negative and 0 if the ratio is negative, where the earnings-to-price ratio is defined as income before extraordinary items and discontinued operations divided by the market value of common equity;

$\mathrm{CAP}_{\mathrm{it}}=$ logarithm of the market value of common equity; 


\section{Macrothink \\ International Journal of Accounting and Financial Reporting ISSN 2162-3082 2019, Vol. 9, No. 1}

$\mathrm{AGE}_{\mathrm{it}}=$ logarithm of number of years firm has been listed on CRSP;

$\mathrm{ATO}_{\mathrm{it}}=$ asset turnover, defined as net sales divided by ADJ_TA $\mathrm{it}_{\mathrm{i}}$;

ADJ_TA $\mathrm{T}_{\mathrm{it}}=$ average of beginning of year and end of year adjusted total assets, where adjusted total assets are equal to total assets plus accumulated depreciation.

\section{Copyright Disclaimer}

Copyright for this article is retained by the author(s), with first publication rights granted to the journal.

This is an open-access article distributed under the terms and conditions of the Creative Commons Attribution license (http://creativecommons.org/licenses/by/4.0/) 